\title{
The Development Process of Awang Sains 2D Digital Mobile Game
}

\author{
Mohd Radhi Md Shukri ${ }^{1}$, Shamsul Arrieya Ariffin ${ }^{2}$ \\ ${ }^{I}$ Faculty of Art, Computing and Creative Industry, UPSI; morashu@yahoo.com \\ ${ }^{1}$ Faculty of Art, Computing and Creative Industry, UPSI; shamsul@fskik.upsi.edu.my \\ https://doi.org/10.37134/jictie.vol6.3.2019
}

\begin{abstract}
This article presents the process of the development of a 2D digital mobile game; Awang Sains. The game has been developed based on features that have been identified, and will be tested for its heuristics - usability, mobility, playability, learning content, local content, language and aesthetics. Fifteen experts were selected to play and then test and evaluate the game. The objective of this game is to use it in teaching and learning Science year 4. The study used design and develop research (DDR) embedded with the ADDIE model (analysis, design, develop, implement, and evaluate), based on pedagogy and the instructional need to make the software meaningful with the ability to help pupils master Science subjects.
\end{abstract}

Keywords: 2D digital mobile game, heuristics, ADDIE.

\section{INTRODUCTION}

Game based learning is described as a game involving specific mechanisms that are appropriate to the situations and problems of learning and that, in addition to featuring teaching, must focus on learning goals (Kovačević, Minović, Milovanović, De Pablos, \& Starčević, 2013; Lester et al., 2014). Digital game based learning is widely used in order to enhance the learning process and has gained a place in Malaysia (Zaibon \& Shiratuddin, 2009). Digital games that incorporate the concept of education and entertainment are also seen as a new innovation that may bring pleasure to pupils during the learning process (Hussain, Tan, \& Idris, 2014). The benefits of using digital games in the classroom have proven their effectiveness, particularly in terms of the positive impact on the teaching and learning process (Klopfer, Osterweil, Groff, \& Haas, 2009; McClarty et al., 2012; Mohamad \& Woollard, 2010; Prensky, 2003).

Nowadays, most digital games are played on the mobile phone platform because the use of these mobile devices provides a new learning atmosphere. Pupils can learn wherever they are (Kim, Rueckert, Kim, \& Seo, 2013). Mobile phones have become a popular tool in daily life, and are used for a variety of purposes, such as communication, medicine, learning, and even business (Hussain, Abbas, Abdulwaheed, Mohammed, \& Abdulhussein, 2015). 
The development of the game was adapted from ADDIE, which was first introduced by Florida State University in 1970. ADDIE stands for analysis, design, development, implementation, and evaluation (Molenda, 2003), and is one of the development models that has been widely used to develop multimedia applications, especially Game-Based Learning (Brook, Burton, Lockee, \& Potter, 2014).

\section{DEVELOPMENT OF AWANG SAINS 2D GAME}

The development of this game software should conform to the developmental characteristics of a teaching aid that has a link between excitement and learning. As stated by Kassim, Nicholas, and $\mathrm{Ng}$ (2014), multimedia-based learning must be designed and developed according to the learning needs. Digital video games that meet the fun and learning features must have mechanical elements, such as visuals, narratives, incentives, appropriate music, and clear academic content and skills (Plass, Homer, \& Kinzer, 2015). Children prefer to play rather than learn seriously. Games are more synonymous with entertainment and fun than learning (Whitton, 2012). Therefore, the use of digital video games as an effective learning tool can only be performed when games are well developed based on the characteristics outlined in education.

\section{Analysis}

The analysis phase is the first site for subsequent phases in teaching design. Brook (2014) stated that this phase involves several processes to determine and identify the problem of the study to be resolved. Once a problem can be identified then the analysis process will be carried out to see and identify the cause or the problem factor. In this phase, an analysis is performed to see what the user will learn (Branch, 2009). Among the activities in this phase are the need to clarify what problems need to be solved, identify the causes of the problems, and find solutions to the problems. The analysis phase involves several aspects such as analysis of users, analysis of the learning environment, and identify the goals of teaching.

Hence, this paper discusses the development of digital mobile games and Science is the subject in which the game will be implemented since Science is a core subject and is compulsory for all primary and secondary school pupils in Malaysia. Hafizan, Halim, and Meerah, (2012) explained that the process of understanding the phenomenon of nature and the process of developing problem-solving skills, expressing interest in scientific attitudes, and innovative thinking are derived from the teaching and learning of Science. If the method and approach of the teacher are not interesting then the pupils will not be interested in the Science subjects, thereby making the pupils weak in this subject (Ismail \& Khairuzaman, 2010). In addition, teacher's role elements, and appropriate use and planning of teaching aids should be considered to attract pupils to learning. A creative form of teaching and presentation style that attracts pupils should be carefully planned so that pupils' learning becomes more meaningful in a shorter time (Yusof, 1997). Tek and Manikam (2014) outlined the development of more organized and structured Science process skills, starting with the introduction of the basic gradual gradation to a more complex level that should be used as a guide by Science teachers. 
To make this digital video game meaningful to pupils, the study will look at the key features of video game development so that it is in line with the needs and fulfils the requirements of software development elements as well as the National Education Philosophy (FPN) of Malaysia. The main requirement to be considered is the curriculum requirements outlined by the Education Ministry. Accordingly, the main reference for this digital game is the 4th year Science textbooks, and the standard curriculum and assessment documents DSKP (Kementerian Pendidikan Malaysia, 2013). All the learning notes and questions are referred to these two main documents.

\section{Design}

This phase is very important in strategy planning for developing teaching techniques and outlines to achieve teaching goals (Smith \& Ragan, 2005). Other features that researchers and developers need to consider are that, in learning how to use digital games, one must be able to turn on player characters, have goals, and a contextual focus that sets them apart from normal games (Ibrahim \& Jaafar, 2009). This will make pupils to focus on learning and so that players do not become disenchanted and run away from the original purpose of the game, i.e., to learn. The learning environment must be controlled and not let the pupil drift away into playing solitary games (Klopster, Osterweil, \& Salen, 2009) and must be focused on or specific to the learning content (Maizatul, 2018; Cheng, Lou, Kuo, \& Shih, 2013).

Most studies focus on the goals for excitement, motivation, and pupil engagement alone and ignore the design, player character, player age, game type or gameplay characteristics that lead to the curriculum. All these elements need to be considered when designing and developing digital video games because the best effect of digital video games is achieved through the combination of the game features and the teaching features (Hainey, Connolly, Boyle, Wilson, \& Razak, 2016).

\section{Character}

In designing the game, the most important is the character that attracts pupils to the game. Hence, we created the character and named him 'Awang'. This character is designed with Malay looks and is wearing "baju Melayu and songkok".

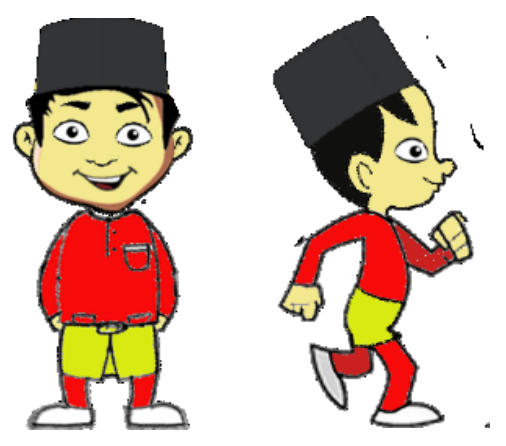




\section{Game level}

Figure 1: Awang Character

Digital video games are usually developed based on certain criteria. The criteria that usually exist in a digital video game are the game, culture, rules and goals. The game refers to the player involvement in terms of interaction and barriers, while the rules are included at the game level. The level of the game is usually from easy to difficult in the player's quest to win. The culture is closely related to the emotions and beliefs of players about the digital video game (Tang, Hanneghan, \& Rhalibi, 2009). The last is the goal or game goal to achieve the target set in achieving the mission and victory (Prensky, 2003).

The game level makes the game more challenging. Hamari et al. (2016) found that in-game challenges have a positive impact on live learning through direct pupil engagement and digital video games development.

In this game we have created three game levels with different challenges and three question levels, so that pupils can have different challenges to obtain the notes and answer the questions correctly. The barriers and challenges enable the pupils' cognitive responses to remember the facts learned in order to score in the game (Yuzie et al., 2015).

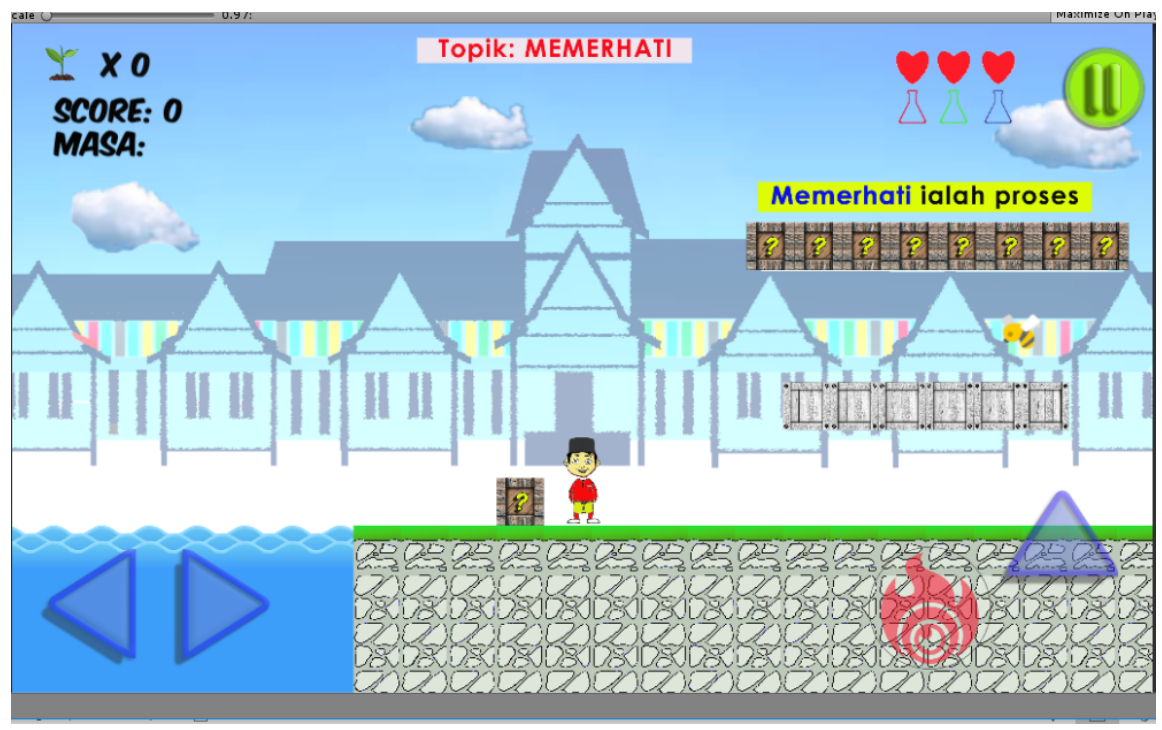

Figure 2: Level 1 


\section{Development}

This level involves the development of a real game by inserting all the elements of media and technology that have been chosen based on the study. Development is a process for developing software or digital games, such as storyboarding, graphics design, and programming (Nisa, 2004). When this phase is developed, the necessary teaching and media steps will be used in teaching and will also look at the documents (Umar, Abdul Rahman, Mokhtar, \& Alias, 2011).

The development of this game software should conform to the developmental characteristics of a teaching aid that links excitement and learning. As stated by Kassim, Nicholas, and Ng (2014), multimedia-based learning must be designed and developed according to the learning needs. Digital video games that meet the fun and learning features must have mechanical elements, such as visuals, narratives, incentives, appropriate music, and clear academic content and skills (Plass et al., 2015). This game has been developed using a video game engine that is available on the market. Such game engines include game maker, Unity 2D, Click2fusion, and touch develop. In this instance, the researcher chose the Unity 2D game engine and certain software, i.e., Adobe Photoshop CC 2018, Microsoft Paint, Autodesk SketchBook, and GNU Image Manipulation Program.

\section{Storyboard Development}

The storyboard was used as a sketch and guide in developing the Science 2D digital mobile game. Four storyboards were developed, i.e., main menu, games menu, question menu, and guidance menu. The storyboard shows what the user interface looks like.

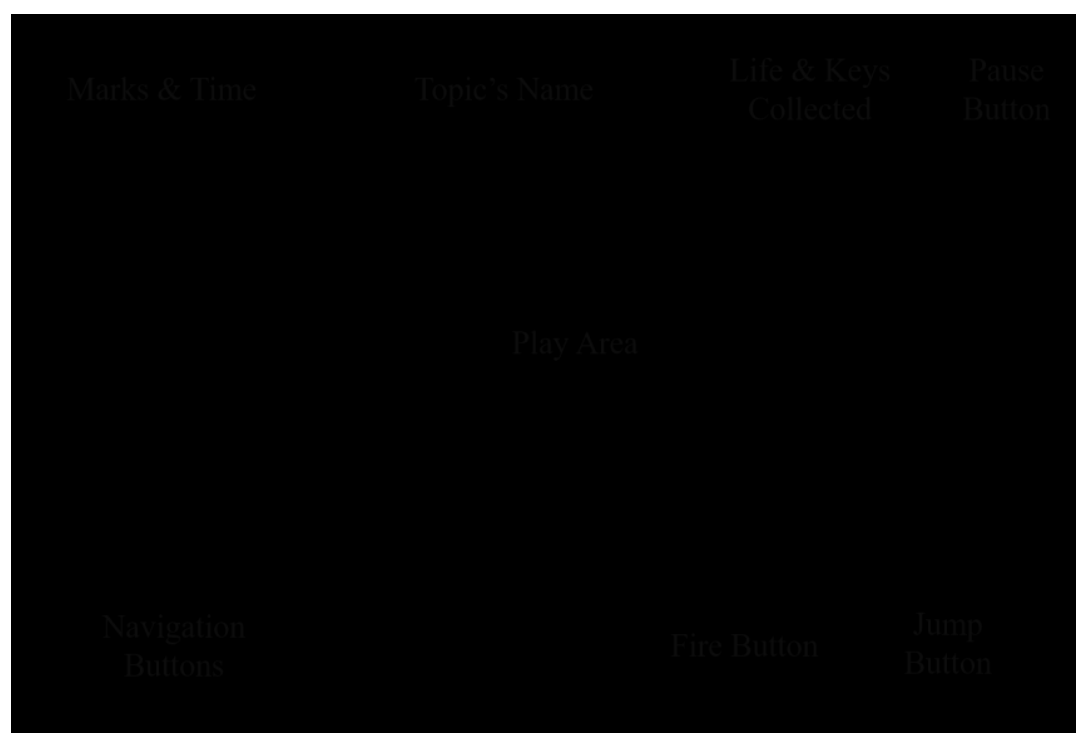

Figure 3: Storyboard for Game Menu. 


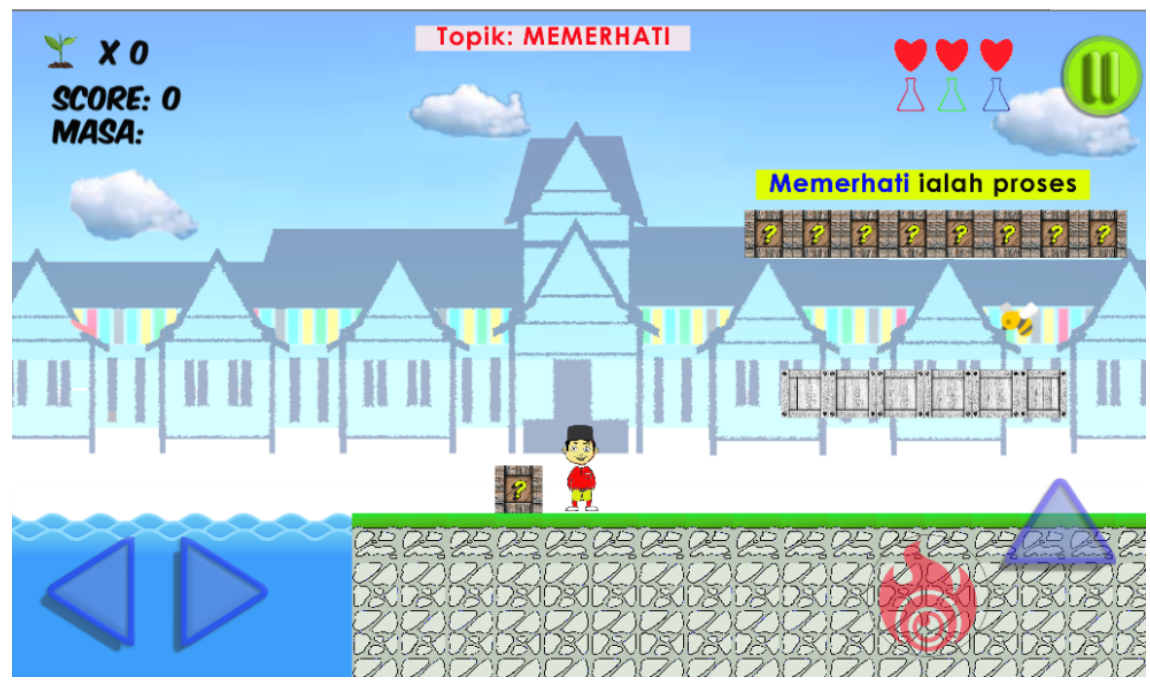

Figure 4: Game menu

\section{Implementation}

The fourth phase process, implementation, comes after development, and is to make sure that the game is free from any error and can run smoothly. Pupils using games in the implementation phase will provide feedback to identify if there is a mistake or error during the process in the development phase (Tan, 2005).

Users can repeat the game process if stranded by the game score cut off. This will ensure that the pupils will always be careful and choose the right answers to each challenge. It requires the pupil to reconstruct each time they start the game (Jeuring, Rooij, \& Pronost, 2013). The repetition process will reinforce the pupil's learning, and will help teach the necessary skills and knowledge with the full willingness of the pupil (Zakirah \& Fadhilah, 2004).

\section{Evaluation}

This is the final phase in the development process. Formative assessment is conducted on a comprehensive basis at all levels to ensure the usability and effectiveness (Hussain et al., 2015). Although Korhonen and Koivisto (2007) combined the elements of how to play, mobility, and playability in designing digital video games, how to play is a key factor in testing the usability and mobility.

The concept of the interaction between humans and computers has become a concern in providing a good experience in using technology. Recently, Murray (2016) contended that gaming user experience 
has made users focus on the concept of human and computer interaction (Human computer interaction HCI). According to Hassenzahl \& Tractinsky (2006), this will take the usability study to a new paradigm. The usability aspect of the game includes gameplay control and game interface, which is central for the gamer to interact with the game. Good usability will make things fun (Salleh et al., 2015). As Korhonen and Koivisto (2007) added, a good game is a game that has an interface that displays all the necessary information and is also easy to control.

In his study, Zaibon (2015) stated that four test components are needed to test the usability of the software: i) usability tests, ii) mobility tests, iii) playability tests, and iv) learning content. However, according to Ariffin and Dyson (2012), most software has no local elements. Therefore, this digital game software will also focus on the content of local elements based on culturally appropriate design guidelines (Ariffin, 2018), which contains suitable local content, aesthetic value, language and local philosophy.

\section{CONCLUSION}

Studies show that well-designed digital games for learning purposes have a positive impact on pupils. They can also introduce a positive change in the learning process (Prensky, 2001). Overmars (2007) stated that games with perfect rules, plus elements of thought and fun will show a good impact on learning. So, based on the research before it shows that learning can be more fun by playing games. Thus, the Science digital game is designed and developed to meet the learning requirements and heuristics will be tested - usability, mobility, playability, and learning content, and the local elements, such as language, local content, and aesthetics - to ensure that the game is ready to play and learn.

\section{REFERENCES}

Ariffin, S. A. (2018). Towards a smart educational environment framework for mlearning in a Malaysian context. Proceedings of the 4th International Conference on Human-Computer Interaction and User Experience in Indonesia, CHIuXiD'18, 74-81.(ACM).

Ariffin, S. A., \& Dyson, L. E. (2012). Student Perspectives On Mlearning For Local Cultural Studies In Malaysia. Cultural Attitudes Towards Technology and Communication, (2010), 135-145.

Branch, R. M. (2009). Instructional design: the ADDIE approach. New York: Springer Science \& Business Media.

Brook, R. L., Burton, J. K., Lockee, B. B., \& Potter, K. (2014). Using the ADDIE Model to Create an Online Strength Training Program: An Exploration, 78. Retrieved from https://vtechworks.lib.vt.edu//handle/10919/47431

Cheng, Y. M., Lou, S. J., Kuo, S. H., \& Shih, R. C. (2013). Investigating elementary school students' technology acceptance by applying digital game-based learning to environmental education. Australasian Journal of Educational Technology, 29(1), 96-110. https://doi.org/10.1234/ajet.v29i1.65

Hafizan, E., Halim, L., \& Meerah, T. S. (2012). Perception, conceptual knowledge and competency level of integrated science process skill towards planning a professional enhancement programme. Sains Malaysiana, 41(7), 921-930.

Hainey, T., Connolly, T. M., Boyle, E. A., Wilson, A., \& Razak, A. (2016). A systematic literature review of games-based learning empirical evidence in primary education. Computers \& Education, 102(January 2004), $202-223$. https://doi.org/10.1016/j.compedu.2016.09.001

Hamari, J., Shernoff, D. J., Rowe, E., Coller, B., Asbell-Clarke, J., \& Edwards, T. (2016). Challenging games help students learn: An empirical study on engagement, flow and immersion in game-based learning. Computers in Human Behavior, 54, 170-179. https://doi.org/10.1016/j.chb.2015.07.045 
Hassenzahl, M., \& Tractinsky, N. (2006). User experience - a research agenda. Behaviour \& Information Technology, 25(2), 91-97. https://doi.org/10.1080/01449290500330331

Hussain, A., Abbas, S. A. A., Abdulwaheed, M. S., Mohammed, R. G., \& Abdulhussein, A. A. (2015). Usability evaluation of mobile game applications: a systematic review. International Journal of Computer and Information Technology, 04(03), 2279-764. Retrieved from www.ijcit.com

Ibrahim, R., \& Jaafar, A. (2009). Educational games ( EG ) design framework : combination of game design , pedagogy and content modeling. International Conference on Electrical, Engineering and Informatics, (August), 293-298.

Ismail, K., \& Khairuzaman, I. (2010). Mengenal pasti faktor-faktor yang menyebabkan pelajar kurang cemerlang dalam mata pelajaran Sains: Satu kajian tinjauan di sebuah sekolah menengah luar bandar. Jurnal Kurikulum \& Pengajaran Asia Pasifik, 3(5), 23-30. Retrieved from http://eprints.utm.my/11384/

Jeuring, J., Rooij, R. Van, \& Pronost, N. (2013). The 5 / 10 method : a method for designing educational games. The 5/10 Method: A Method for Designing Educational Games, 8.

Kassim, H., Nicholas, H., \& Ng, W. (2014). Using a multimedia learning tool to improve creative performance. Thinking Skills and Creativity, 13, 9-19. https://doi.org/10.1016/j.tsc.2014.02.004

Kim, D. D., Rueckert, D., Kim, D. D., \& Seo, D. (2013). Students ' perceptions and experiences of mobile learning. Language Learning and Technology, 17(3), 52-73.

Klopfer, E., Osterweil, S., Groff, J., \& Haas, J. (2009). Using the technology of today, in the classroom today. Massachusetts Institute of Technology: The Education Arcade. Retrieved from http://education.mit.edu/papers/GamesSimsSocNets EdArcade.pdf

Korhonen, H., \& Koivisto, E. M. I. (2007). Playability heuristics for mobile multi-player games. Proceedings of the 2nd International Conference on Digital Interactive Media in Entertainment and Arts-DIMEA '07, 28. https://doi.org/10.1145/1306813.1306828

Kovačević, I., Minović, M., Milovanović, M., De Pablos, P. O., \& Starčević, D. (2013). Motivational aspects of different learning contexts: "My mom won't let me play this game..." Computers in Human Behavior, 29(2), 354-363. https://doi.org/10.1016/j.chb.2012.01.023

Lester, J. C., Spires, H. A., Nietfeld, J. L., Minogue, J., Mott, B. W., \& Lobene, E. V. (2014). Designing game-based learning environments for elementary science education: A narrative-centered learning perspective. Information Sciences, 264, 418. https://doi.org/10.1016/j.ins.2013.09.005

Maizatul Hayati Mohamad Yatim (2018). Lessons learned in game playing activities using playtesting in a game-based learning approach. In proceedings of $8^{\text {th }}$ UPI-UPSI International Conference 2018. https://doi.org/10.2991/upiupsi-18.2019.22

McClarty, K. L., Orr, A., Frey, P. M., Dolan, R. P., Vassileva, V., \& McVay, A. (2012). A literature review of gaming in education. New York: Pearson. https://doi.org/http://dx.doi.org/10.1108/17506200710779521

Mohamad, M., \& Woollard, J. (2010). Bringing change in seconday schools: can mobile learning via mobile phones be implemented in Malaysia? 4th International Malaysian Educational Technology Convention. Kuala Lumpur, 1-13.

Molenda, M. (2003). In search of the elusive ADDIE model, (June), 34-36.

Murray, T. (2016). Coordinating the Complexity of Tools, Tasks, and Users: On Theory-based Approaches to Authoring Tool Usability. International Journal of Artificial Intelligence in Education, 26(1), 37-71. https://doi.org/10.1007/s40593-0150076-6

Nisa, K. (2004). Rekabentuk Instruksional Berdasarkan Model ADDIE : Analisis Kajian Di Emporia State University Korea Selatan Dan Universiti Teknologi Malaysia. Universiti Pendidikan Sultan Idris, 1-7.

Overmars, M. (2007). Game Maker tutorial: designing good games. YoYo Games Ltd., 1-17.

Plass, J. L., Homer, B. D., \& Kinzer, C. K. (2015). Foundations of game-based learning. Educational Psychologist, 50(4), 258283. https://doi.org/http://dx.doi.org/10.1080/00461520.2015.1122533

Prensky, M. (2003). Digital game-based learning. ACM Computers in Entertainment, 1(1), 21 https://doi.org/10.1145/950566.950596

Salleh, N. S. M., Din, R., Manaf, S. Z. A., Hamdan, A., Karim, A. A., Education, P., \& Kebangsaan, U. (2015). Kesahan dan Kebolehpercayaan Soal Selidik Kebolehgunaan Modul Pembelajaran Kendiri Menggunakan Model Pengukuran Rasch ( Validity and Reliability of Questionnaire to Measure Usability of a Self-Learning Module Using the Rasch Measurement Model ). Journal of Advanced Research Design, 8(1), 1-11.

Smith, P. L., \& Ragan, T. J. (2005). Instructional design. New York: McMillan Publishing Company.

Syed Hussain, S. Y., Hoe, T. W., \& Idris, M. Z. (2014). Digital game-based learning for remedial Mathematics students: a new teaching and learning approach in Malaysia. International Journal of Multimedia and Ubiquitous Engineering (IJMUE), 9(11), 325-338. https://doi.org/10.3850/978-981-09-0463-0

Tan, C. (2005). Analysis of three instructional design models. De-Research, 1-18.

Tang, S., Hanneghan, M., \& Rhalibi, A. (2009). Introduction to games-based learning. Games Based Learning Advancements for Multi-Sensory Human Computer Interfaces. New York: IGI Global. https://doi.org/10.4018/978-1-60566-360-9.ch001

Tek, O. E., \& Manikam, S. (2014). Penguasaan kemahiran proses sains asas dalam kalangan murid India di beberapa buah sekolah rendah di Perak. Jurnal Sains Humanika, 2020(2010), 135-144. https://doi.org/10.11113/SH.V2N1.389 
Umar, R. S., Abdul Rahman, F., Mokhtar, F., \& Alias, N. A. (2011). Menggunakan animasi di dalam instruksi khas untuk kanakkanak disleksia. Jurnal Teknologi Pendidikan Malaysia, 1(2005), 27-38.

Whitton, N. (2012). The place of game-based learning in an age of austerity. Electronic Journal of E-Learning, 10(2), 249-256 Yusof, H. (1997). Media pengajaran untuk pendidikan dan latihan. Shah Alam: Fajar Bakti.

Yuzie, A., Arshad, M., Pendidikan, F., Yasin, R. M., Pendidikan, U., \& Idris, S. (2015). Kemahiran Berfikir Aras Pelajaran Sains. Asian Education Action Research Journal, 4, 81-96. Retrieved from http://ejournal.upsi.edu.my/article/2016AR000694

Zaibon, S. B. (2015). User testing on game usability, mobility, playability, and learning content of mobile game-based learning. Jurnal Teknologi, 3, 57-61.

Zaibon, S. B., \& Shiratuddin, N. (2009). Local content game: The preferred choice for mobile learning space. Proceedings Ascilite Auckland 2009, 684-694. Retrieved from http://ascilite.org.au/conferences/auckland09/procs/norshuhada.pdf

Zakirah, O., \& Fadhilah, Y. M. (2004). Tinjauan Permainan Berkomputer Sebagai Alat Pembelajaran. Computer, 1-9. Retrieved from http://repo.uum.edu.my/1512/1/TINJAUAN_PERMAINAN_BERKOMPUTER.pdf 